\title{
I La Galigo Folklore Illustration on Textile Media
}

\author{
Yosepin Sri Ningsih, John Martono \& Zaini Rais \\ Fakultas Seni Rupa dan Desain, Institut Teknologi Bandung, \\ Jl. Ganesa 10, Bandung 40132 \\ Email: yosepinsri@gmail.com
}

\begin{abstract}
This project was an effort in conserving the I La Galigo epic story while at the same time adding value to silk, the famous textile product from South Sulawesi and the origin of I La Galigo. As a work of literature, I La Galigo is categorized as an epic. It is known locally as Sureq Galigo in Bugis. It is divided in a number of episodes or tereng. The most well-known tereng is the one which describes the relationship between Sawerigading and a princess called I We Cudai. From that relationship I La Galigo, the central character of this epic is born. For this project six of the most well-known episodes were selected because of the amount of available supporting data, both theoretical and visual. The selected episodes were translated from their original narrative form into visual language or images. The illustration technique used in this project was STP (Space Time Plane). With this technique every object is drawn from varying viewpoints in one frame, both in space and time. Hand embroidery was added to the painted images. The silk painting can be used as an interior element with value added by the I La Galigo illustrations.
\end{abstract}

Keywords: I La Galigo; epic; Sulawesi; illustration; silk painting; space time plane.

\section{$1 \quad$ Introduction}

Dozens of tribes in the Indonesian archipelago have produced thousands of manuscripts, written in various languages and scripts. One that receives a lot of attention from the experts is I La Galigo, an epic written by the Bugis ethnic people using a Bugis script. Epic folklore such as I La Galigo is an important part of of Indonesian culture, just as well as its traditional dresses, dances and traditional houses, and therefore needs to be preserved.

I La Galigo is a character, a child from the couple Sawerigading and his wife I We Cudai. Sawerigading is the grandson of Batara Guru, the god who descended from heaven to earth to fill the vacuum on Earth, and his wife I We Cudai was a Chinese princess. The name I La Galigo was used for the title of the book by R.A. Kern (a collection of 39 Sureq Galigo manuscript summaries) [1], as well as for its translation by La Side and Sagimun [2] and for the the library of books and transliterations that is stored in Leiden, the Netherlands, as

Received September $3^{\text {rd }}, 2012$, Revised October $9^{\text {th }}, 2013$, Accepted for publication December $3^{\text {rd }}, 2013$. Copyright (C) 2014 Published by LPPM ITB, ISSN: 1978-3078, DOI: 10.5614/itbj.vad.2014.6.1.1 
a gift of the nobleman Arung Pancara Toa to the Dutch researcher Dr. B.F. Mathes.

The epic, which is also known as Sureq Galigo or Sureq Selleang, meaning 'golden letters', is the longest epic in the world, consisting of approximately 300,000 lines, which makes it longer than the Mahabharata, which consists of 200,000 lines less. Despite its long story, this epic is not as well-known as we presumed at the time this research was started. As Rahman [3] stated, manuscripts written in indigenous scripts, both those on paper and a few on lontar leaves, are commonly known as lontaraq, a word derived from the Javanese word 'lontar'. The story is divided into a number of episodes, known as tereng. Tereng, which are widely known by the Bugis people, describe the marital relationship between Sawerigading and I We Cudai.

This research was undertaken in order to preserve the I La Galigo folklore, the world's longest epic that is an important part of the Indonesian archipelago's cultural heritage, so it can be passed on to future generations. Silk, as a textile icon that is also full of history, would be an appropriate medium to pour the epic folklore into, which could simultaneously increase the value of the silk fabric.

What initially brought the authors to this research was the emergence of a variety of questions related to the popularity of the manuscript. Is I La Galigo as part of the world's literary heritage actually popular in Indonesia? How is it popular, as folklore or only as a local name? How to use silk as a textile that is categorized as a high-class fabric that also being popular in South Sulawesi? Further study revealed that I La Galigo was allegedly composed in the $14^{\text {th }}$ century and passed on as part of an oral tradition, and then written on lontar leaves using paku letter. From this we can conclude that the story had two dispersal methods: one through oral language and the other one through written language. The Sulawesi community has a high appreciation of literature and is not only concerned with literary values but also with human values, as reflected in the characters.

For the illustration silk cloth was used as the medium. Silk was chosen because it is a fabric that evokes Sulawesi, and was worn by kings and nobles among the Bugis, as mentioned in these sureq (the sureg mention that the kings was wearing the silk fabric as their clothes). The scope of this study includes four aspects: the limited part of the epic story that will be imaged: from the moment when Datu Patoto sends his son to Earth to the moment when I La Galigo is born, who is his 4th descendant. The second aspect is the application of an imaging system using the STP technique (Space Time Plane). The third aspect is the use of silk organdy as the medium, a type of silk fabric that is transparent. 
The final aspect is the use of silk painting and hand embroidery as techniques for applying the images to the medium. Data collection and review consisted of three parts, namely: literature study, a questionnaire and interviews.

\section{Research Methods}

I La Galigo is a folklore that has been passed on from generation to generation, maintaining an old ancestrial tradition. Other visual stories that are part of tradition are: wayang stories (Wayang Beber), stories on batik cloth, the stories on the Borobudur temple reliefs, and other historic images. Tabrani [4] calls these pictures 'tradition imageries' (Bahasa Rupa Tradisi).

The method they use is Space Time Plane, where space and time are not separated. In this method a story that is poured into the form of images also has a certain order, like language, which uses grammar rules. Imaging rules are part of the image system and imaging process. The image system covers a broad range of meanings of either the visible or the imaginary. The imaging of the data from a story, and perhaps also some representative pictures, is called the wimba. A wimba is divided into two parts, namely the content and the wimba manner (method). For example, Wimba content are objects that are drawn, such as Sawerigading figures, while the wimba manner (method) is the way of describing Sawerigading.

Translating the wimba into a story is done by following the procedures of the expression system (tata ungkapan). The expression system has two aspects, namely the inner expression system - a method to translate the wimba and the wimba manner into single-frame images - and the external expression, which is an image transfer technique. On this occasion, the wimba from the whole I La Galigo epic will not be explained, as it would takes too much time to discuss. This paper discusses the formation of a wimba for one representative episode and its expression system as well as its application to the silk organza medium.

Sulawesi began to weave silk at the end of 16 th century. Before that, silk was a luxury item which was only imported from outside [5]. The methods for decorating silk fabric included techniques such as silk painting and embroidery. Numerous processing and coloring techniques, found to this day, that are used to decorate woven silk and cotton come from India and China. Malam, as used in the batik technique, goes back to the second century BC. After it was first introduced in Java, the batik industry developed rapidly and Java became the center of the batik industry. Gutta, which became part of silk painting, may be the result of developments in the resist technique (a property of malam in batik). Another technique used is embroidery (hand embroidery or machine embroidery), which is not an prominent technique, but only a supplementary 
one. Machine embroidery and hand embroidery techniques can give expression to the characters and create texture and render the work in a unique way. As a matter of fact, hand embroidery also appears in I La Galigo, "The La Galigo text also mentions many kinds of embroidered clothes with various names of which the meaning is unknown." [6]

\section{$3 \quad$ Results and Discussion}

The research consisted of two main parts. First, conceptualizing the images using the STP system and second their application to the textile medium (silk) by silk painting techniques and hand embroidery. In the image conceptualization process, the story was confined to a number of chapters/episodes/tereng. In this research the story of La Galigo is divided into 6 (six) tereng. In each episode, a character and figure investigation were conducted to shape each wimba and their attributes, as well as backgrounds such as time and space settings. Filling in the background settings was different for each episode, depending on the plot. The following paragraph is an explanation of the STP method that has been developed.

The contents of the wimba in the I La Galigo silk paintings were made with reference from the book The Birth of I La Galigo [7]. The wimba method was determined based on theoretical data and images that have been collected from other sources. These data were then imaged again, according to the individual style of the researcher. In this study all wimba were not naturalistic (naturalistic representations), some were based on the painter's imagination and others are based on found artifacts.

The expression system defined the background with space systems; some were based on the ground, some on the sea. To express motion, multiple imaging (such as one character repeated many times over) and distortion techniques were used, as can be seen in images of feet and hands. Time was expressed with composition and wimba such as the sun and moon images. Noblemen's figures were depicted with the attributes of nobility and beautiful clothes. The external expression was created by the method of ordering the images from top to bottom, so that each episode shown always flashes forward chronologically from the first painting to the sixth painting. Once the concept drawings were finished, the pictures were converted into silk painting, machine embroidery and hand embroidery.

According to Yunus [8] silk was found more than 2500 years BC in China. Silk is the 4th natural fiber found after linen, wool, and cotton. An old tale says that the inventor was a Chinese empress named Si Ling Chi. She accidentally dropped a cocoon into a hot cup of tea that she was drinking. The tea became 
more viscous by the cocoon that dissolved in the tea. From that solution an unbroken thread of fine fibers germinated, approximately $500 \mathrm{~m}$ long. The accidental inventor so became the initiator of the silk industry in China.

In the book entitled Manusia Bugis by Pelras [5], silk usage can be seen in the everyday life of the Bugis people (as mentioned before): "In the La Galigo manuscript it is mentioned that these clothing materials were derived from a variety of expensive imported fabrics, including patola fabric (double silk bundle from Gujarat), specifically patola uleng (moon patterned Patola), and also patimanangi, which has an important function in ritual ceremonies. Another type of fabric used in various ceremonies, expensive silk fabric imports, was unidentified. For example, the sarong material sarebba which is made from silk was used, as well as Wajang mpatara (shadow of heaven), maleo Kelling, darati Kelling, along with Malaju and Parengki. While Setti or setting (possibly satin silk) and sunrupi were used as clothing material." These silk materials are only mentioned by Pelras in the book, there are no data that describe their visual character or visual attributes. In other books and sources there are some boat illustrations and sailing illustrations, as well as pictures of traditional houses.

\section{$4 \quad$ Application on Silk Fabric}

The final sketches of the episodes were painted on a piece of organza silk fabric with a size of $90 \mathrm{~cm}$ wide and $120 \mathrm{~cm}$ long. One of this fabric's properties is transparency, which enables the paintings to be seen from two sides and makes the way of reading adjustable.

The working process was as follows:

1. Preparation. The Wimba illustrations were printed on A0 size chalkier paper, which was used to transfer the illustration onto a screen-printing frame.

2. Tracing and printing. The silk fabrics were stretched out on a table coated with glue on top in order to fix it so the fabric could not move while being printed. The stencil ink that was used contained a fraction of rubber; the screening process was used to make an outline picture that looked neat and precise, and to resist paint from the outlines.

3. Painting - coloring. Because the chosen medium was organza silk fabric, the coloring technique that was used was silk paint with water color brushes, which are suitable to the paint's properties. (See Figure 1)

4. Heat fixation. After being colored the fabric was ironed in order to make the colors blend with the fabric perfectly (the method depends on the type of silk paint; some paint types/brands need steaming before being ironed). 
5. Hand and machine embroidery. This process was used for some wimba, not for all of them. This process can give a striking expression to the wimba in accordance with the character that is plotted. (See Figure 2)

6. Framing. This process was added to make the paintings easier to read and display. (See Figure 3)

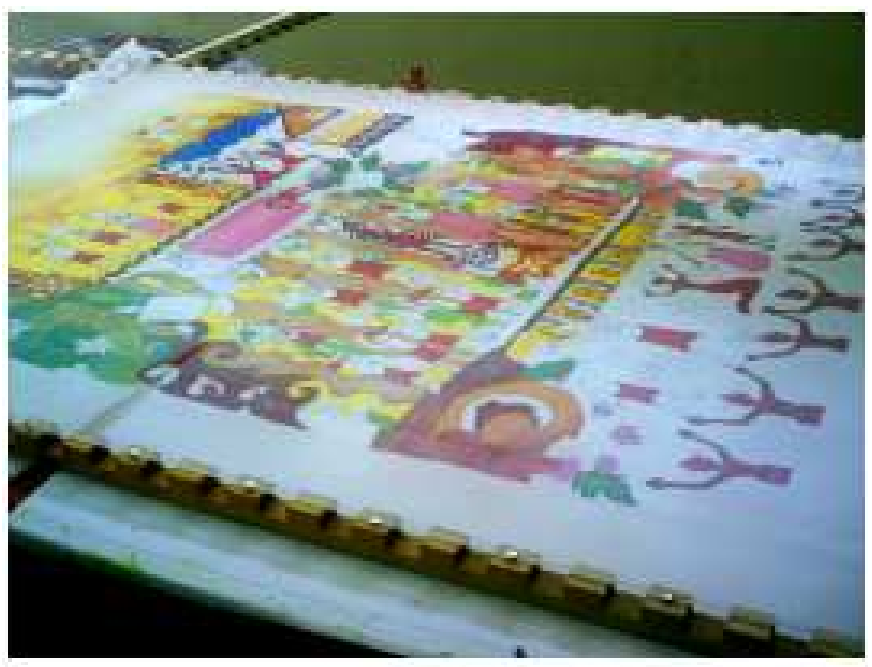

Figure 1 Coloring process, the fabric being mounted into a portable frame.

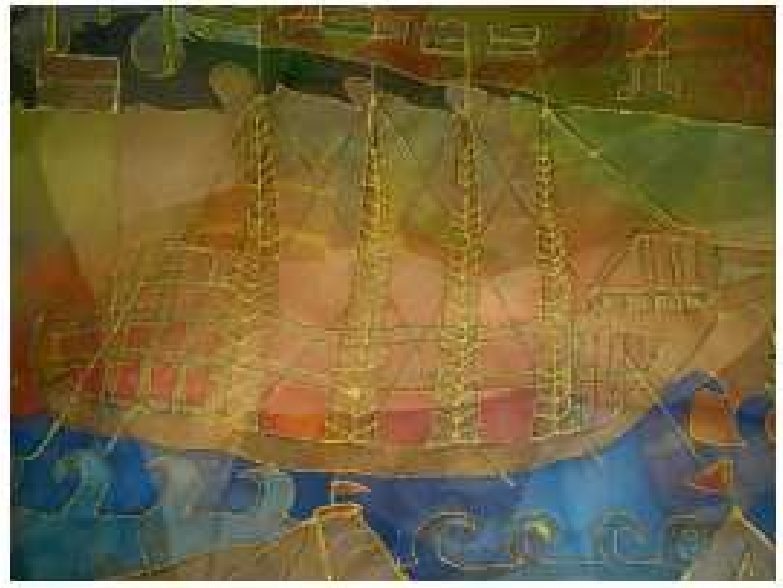

Figure 2 Detail of the embroidery on the product. 


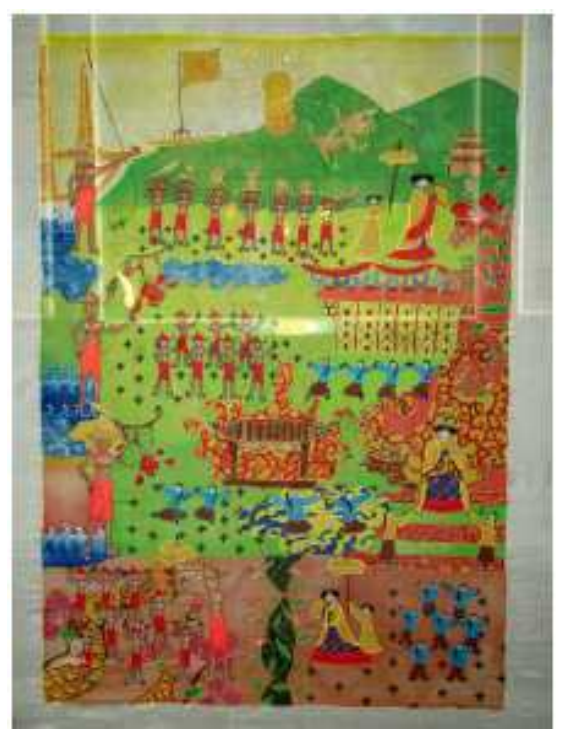

Figure 3 The 4th episode of the final product.

\section{Conclusions and Suggestions}

Through a series of processes, the I La Galigo Epic was visualized using the Space Time Plane method as discussed in this paper. This proved to be sufficient and adequate, because STP is a representation technique commonly used in East Asia. The I La Galigo folklore is the world's longest epic and is part of the world's literary heritage, so it has great historical and cultural value. It can be categorized as 'high-class' literature and for this reason silk was chosen as the medium, because the noblemen among the characters generally wear clothes made from the same fabric. Technically, there were some difficulties that occurred during the process of this research, such as the difficulty of finding image data, for which the research locations are quite far (some in Makassar and others in Leiden, the Netherlands).

The selected size of the paintings is A0 in portrait position, with a $90 \mathrm{~cm}$ width and $120 \mathrm{~cm}$ length. The size is the maximum size of a screen-printing setup. The outlines had to be neat and precise, so it was decided to choose a screenprinting technique. It turned out that stencil/printing ink can have the same function as gutta ink in silk painting. The screen-printing technique can be successfully applied to organza silk fabric, but not so well to sateen silk fabric because of its specific character. The latter has a more tight weaving so that the ink spreads out more easily from the outline boundaries of the screen-printing result. For this reason an organza silk fabric was used. The weave of this fabric 
is more tenuous, so that the ink can penetrate easier without flowing over (out of the outline boundaries).

This research involved various aspects of scientific disciplines such as anthropology and visual communication, and was enhanced by craftsmanship to add to the uniqueness of the paintings. In such a process the difficulty is to achieve an accurate visualization. This research is a preliminary research and requires further study of the I La Galigo epic itself and the relationship between silk painting techniques and the I La Galigo epic. Because of the limited time available for exploration in this research, the silk painting method was chosen because it is easier in the visualization process compared to weaving, and can create different effects, such as a color gradation.

\section{References}

[1] Kern, R.A. 1989. I La Galigo, Gajah Mada University Press.

[2] Side \& Sagimun, M.D. 1989. I La Galigo: Cerita Bugis Kuno, Yogyakarta: Gadja Mada University Press.

[3] Rahman, N., Hukma, A. \& Anwar, I. 2006. La Galigo Menelusuri Jejak Warisan Sastra Dunia, Pusat Studi La Galigo Universitas Hasanudin dan Pemerintah Kabupaten Baru, Makassar.

[4] Tabrani, P. 2005. Bahasa Rupa, Kelir, Bandung.

[5] Pelras, C. 2006. Manusia Bugis, NALAR, Jakarta.

[6] Abbas. 2001. Album Kepurbakalaan Sulawesi Selatan, Ministry of Culture and Tourism, South Sulawesi.

[7] Damono, S.D. 2005. The Birth of I La Galigo, The Lontar Fondation, Jakarta.

[8] Yunus, K.P. 1998. Analisa Bentuk Dasar dan Hiasan Rumah Tradisional Sulawesi Selatan, M.S. thesis, Dept. Art and Design, Institute Technology of Bandung, Bandung, Indonesia, 1998. 